\title{
Pensonomonoor
}

2014, vol. 72, 29-39

http://dx.doi.org/10.12657/denbio.072.002

\author{
Marta Joanna Monder, Maciej Niedzielski, Konrad Woliński
}

\section{Effect of rooting preparations on protein, chlorophyll and carotenoid content in leaves of Rosa gallica 'Duchesse d'Angoulême' cuttings}

\author{
Received: 06 May 2013; Accepted: 20 December 2013
}

\begin{abstract}
Popularisation of historical rose cultivars is important for overall increase of biodiversity within currently available assortment, however their vegetative propagation is rather difficult. Possible scenario behind it is that commonly used one-bud leafy cuttings have limited storage capacity due to the small size of the stem. We hypothesised that the treatment of cuttings this rose with rooting preparations would positively affect on the condition of their leaves. We tested the effect of preparations based on seaweed extracts (Bio Rhizotonic, Root Juice, Bio Roots) as well as commonly used root stimulants (Ukorzeniacz $\mathrm{A}_{\text {aqua }}$ and Ukorzeniacz $\mathrm{B}_{\text {aqua }}$ containing $0,4 \%$ IBA or $0,2 \%$ NAA respectively) on the viability potential of the Rosa 'Duchesse d'Angoulême' cuttings. We have monitored the senescence process in leaves by the total soluble protein, chlorophyll and carotenoid content measurements. In order to test the potential effect of the mother plant and timing of shoots acquirement cuttings for the experiment were taken from mother plants at four different maturity stages (flower buds closed; all flowers open; just after petal fall and 7-14 days after petal fall). As expected the amount of the measured components in mother plants varied in individual phases of shoot maturity. This feature influenced the positive effect of rooting stimulants on cuttings viability. The most striking effects were in rooted cuttings derived from shoots collected just after flower petal fall. Observed increase in soluble protein and chlorophyll content did not correlate however with the percentage of obtained rooted cuttings. Based on that we can speculate that the biological basis of observed positive effect of natural rooting preparations on the 'Duchesse d'Angoulême' rose is complex and does not rely on the delay or inhibition of senescence process.
\end{abstract}

Additional key words: rhizogenesis, historical roses, leaf senescence, shoot maturity.

Address: M.J. Monder, M. Niedzielski, K. Woliński. Polish Academy of Sciences Botanical Garden - Centre for Biological Diversity Conservation in Powsin, Prawdziwka 2, Warsaw, Poland, e-mail: mondermarta@obpan.pl

\section{Introduction}

The historical roses are valued for their high resistance to unfavourable growth conditions, especially frost, and popularisation of such cultivars is important for overall increase of biodiversity within currently available assortment. One of them with the highest decorative value (Monder 2007), is Rosa gallica 'Duchesse d'Angoulême', bred by Vibert in 1821 (Quest-Ritson and Quest-Ritson 2003).

Propagation of cultivars derived from many rose species such as Rosa gallica 'Duchesse d'Angoulême' 
by means of shoot cuttings is considered to be difficult (Hoşafçi et al. 2005; Moroz 2006), and the rhizogenesis process in nursery conditions is time-consuming (Moroz 2006). It has been shown, that in softwood and semi-hardwood cuttings in woody plants the amount of reserves is usually a limiting factor for survival and further growth (Okoro and Grace 1976). In rose, single node leafy stem cuttings, have also limited storage capacity due to the small size of the shoot. Thus, the opportunity of cuttings to photosynthesis during propagation should be the main regulatory factor of survival and subsequent growth (rooting, growth of the auxiliary bud into primary shoot and dry weight accumulation) (Costa 2002). The decreasing of chlorophyll content and increasing of carotenoids is associated with leaf senescence process (Afitlhile 1993; Gitelson and Merzlyak 1994). It's been shown that certain growth regulators have a significant influence on the chlorophyll and carotenoid levels (Volfová et al. 1978; Czerpak et al. 2002). Using various growth regulators inhibits chlorophyll degradation, also in leaves of cut flowers, where the process of ageing takes place (Ranwala and Miller 2002; Skutnik and Rabiza-Świder 2004). During the vegetative propagation commercially available formulations based on auxin are used, however to our knowledge their influence on chlorophyll and carotenoid level has not been widely described.

The use of biostimulants is another strategy for improvement of cuttings viability. In order to protect environment, the EU Council Directive (EU Council Directive no. 91/414/EEC 1991) was enacted that encourages limiting the use of chemicals in plant production and introducing integrated methods of cultivation and protection. Biopreparations are also recommended by the National Organic Program USDA (www.ams.usda.gov/AMSv1.0/NOP) and Organic Materials Review Institute (OMRI) (www. omri.org/sites/default/files/opl_pdf/complete_company.pdf). A lot of research is being done on biostimulants used in plant cultivation (Cambri et al. 2008; Pruszyński 2008; Khan et al. 2009). In particular the positive influence of algae preparations has been repeatedly confirmed (Cambri et al. 2008; Khan et al. 2009; Thorsen et al. 2010). They contain compounds of natural origin, and the effectiveness of their action depends on their protein and phytohormone composition content (Couée et al. 2004; Cambri et al. 2008; Jannin et al. 2013). These active compounds may stimulate rhizogenesis by inducing morphological and biochemical changes in plants (Cambri et al. 2008). They are used in nurseries to improve the efficiency of rooting (Bellach et al. 2009) and protect cuttings from diseases (Wojdyła 2004; Khan et al. 2009). However, limited scientific information is available to support the positive effect of biostimu- lants on biologically active components in leaves of difficult-to-root plants including rose.

According to research of Whaphman et al. (1993) and Jannin et al. (2013) seaweed extracts prevent decrease of photosynthetic pigments and their use was correlated with increased level of proteins. This phenomenon has been linked to the positive effect on the survival of cuttings.

We believe that long time of rooting exposes cuttings of Rosa gallica 'Duchesse d'Angoulême' to prolonged stress and senescence process in leaves. The condition of leaves may correlate with percentage of rooted cuttings. Taking account all the above factors, a hypothesis was made in the study that the treatment of cuttings this rose with rooting preparations would positively affect on the condition of their leaves. Additionally, we expected differential impact of the phase maturity of shoots cut to rooting. The aim of our research was understanding of the correlation between the starting levels of the soluble proteins, chlorophyll $\mathrm{a}$ and $\mathrm{b}$ and carotenoids at the time of cutting excision and corresponding levels after rooting. In particular the influence of the above parameters over the positive action of biostimulants has been taken into account. The effect of environmental friendly biopreparations based on seaweeds extract (Bio Rhizotonic - "Canna Continental", Netherlands; Root Juice - "BioBizz Worlwide N.V.", Netherlands; Bio Roots - "General Hydroponics Europe", France), on the rhizogenesis process during the progress of the cuttings senescence has also been examined.

\section{Materials and methods}

Material for the research were leaves of Rosa gallica 'Duchesse d'Angoulême' taken from cuttings, rooted in standard conditions in a foil tunnel $\left(23-25^{\circ} \mathrm{C}\right.$, ambient relative humidity $80-90 \%$ ) in the commercial nursery of M. M. Kryt in Wola Prażmowska $\left(51.56^{\circ} \mathrm{N}\right.$, $20.28^{\circ} \mathrm{E}$ ) in 2011 . Shoots used as input material in the experiment were cut from mother shrubs growing in the Polish Academy of Sciences Botanical - Centre for Biological Diversity Conservation in Powsin, in the following maturity phases: flower buds closed (May 31); all flowers in an inflorescence open (June 9); just after petal fall (June 17); 7-14 days after petal fall (June 29) (Fig. 1 a). The single node leafy stem cuttings (Fig. $1 \mathrm{~b}$ ) were planted in multipot trays $(6,6 \times 6,6 \mathrm{~cm})$, in the peat substrate $(\mathrm{pH} \mathrm{6-6.5).} \mathrm{The}$ cuttings were treated with standard rooting powders: Ukorzeniacz $\mathrm{A}_{\text {aqua }}\left(0.4 \%\right.$ IBA) and Ukorzeniacz $\mathrm{B}_{\text {aq- }}$ иа $(0.2 \% \mathrm{NAA})$ ("Himal", Poland), or watered with solutions of the biostimulants: Bio Rhizotonic, Root Juice and Bio Roots. The treatments were conduct- 
ed according to manufacturer's instructions and description of watering is specified in detail in Table 1.

After 12 weeks the percentage of rooted cuttings was counted. Leaves, for qualitative and quantitative analysis of the soluble protein fraction as well as the measurement of the amount of chlorophyll $\mathrm{a} / \mathrm{b}$ and carotenoids were sampled twice: at the day of cutting from shoots in four maturity phase of mother plants and in August - after 12 weeks of rooting period (from rooted segments of shoots - the leaf derived from mother plant only). Additionally in order to compare changes in studied photosynthetic pigments content across the whole vegetation period leaves were harvested in August from analogical overblown shoots of mother plants in collection.

The samples were frozen and kept at the temperature of $-18^{\circ} \mathrm{C}$ until analysed. Research was carried out in the Department of the Evaluation and Plant Biodiversity Conservation of the PAS BG CBDC in Powsin.

\section{Protein extraction}

The same protein extracts were used for the evaluation of the total protein content as well as the qualitative estimation of the electrophoretic profile using the Laemmlie SDS-PAGE discontinuous system (Moberg et. al. 1987). A sample of around 100 mg of frozen leaves was extracted three times (30 min. each time) with the $1 \mathrm{ml}$ of extraction buffer containing $0.063 \mathrm{M}$ TRIS, $2 \%$ SDS, 5\% $\beta$-mercaptoethanol, $10 \%$ glycerol. Each sample was denatured for 5 minutes in a water bath at $98^{\circ} \mathrm{C}$ and subsequently centrifuged at room temperature for $20 \mathrm{~min}$. at $10000 \mathrm{~g}$. Protein concentration has been estimated according to the modified method of Ghosh et al. (1988).

\section{Total protein content measurement}

The $10 \mu \mathrm{l}$ portions of the supernatant were marked on squares of Whatman $3 \mathrm{MM}$ blotting paper placed in cells of cultivation plates. After drying at $35^{\circ} \mathrm{C}$ for discolouration, $15 \mu \mathrm{l}$ of the solution of CBB R-250 $(0.2 \%)$ in $(40 \%)$ methanol and $(10 \%)$ acetic acid was sprinkled on the blotting paper. After 20 minutes, the excess of the pigment was eluted with methanol and acetic acid. After drying, it was moved to test tubes and the protein-pigment complex was eluted with $1 \%$ SDS in an ultrasonic washer for 1 hour. Absorption of the eluate was assessed at a wave length of $590 \mathrm{~nm}$ (spectrophotometer Gene Quant 1300, GE). The protein content was calculated based on the standard curve for BSA solutions.

\section{Electrophoretic separation of proteins}

Samples of protein extract of $25-30 \mu l$ were placed on a polyacrylamide gel and separated vertically (Hoefer SE 600), with the amperage of $30 \mathrm{~mA}$ in a stacking gel (T 3\%) and $45 \mathrm{~mA}$ in a separating gel (T $10 \%)$. The analysis was carried out from transition of the trace dye front (bromophenol blue) at a distance of around $1 \mathrm{~cm}$ from the lower edge of the gel. After removing from the apparatus, the gels were stained for 30 minutes in the solution of Coomasie Brilliant Blue (CBB) R-250 (0.25\%) in methanol (40\%) and acetic acid (10\%). Finally gels were de-stained until the colour background disappeared, dried out and visually examined.

\section{Chlorophyll and carotenoid}

For chlorophyll and carotenoid measurements 0.1 $\mathrm{g}$ leaf tissue was ground to a powder in liquid nitrogen using a mortar and pestle followed by extraction (a)

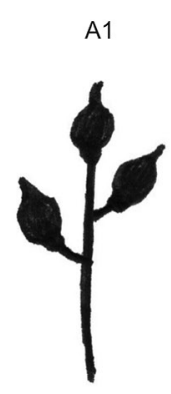

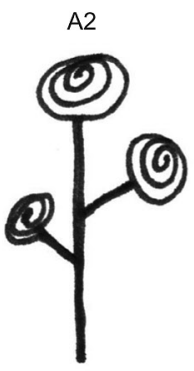
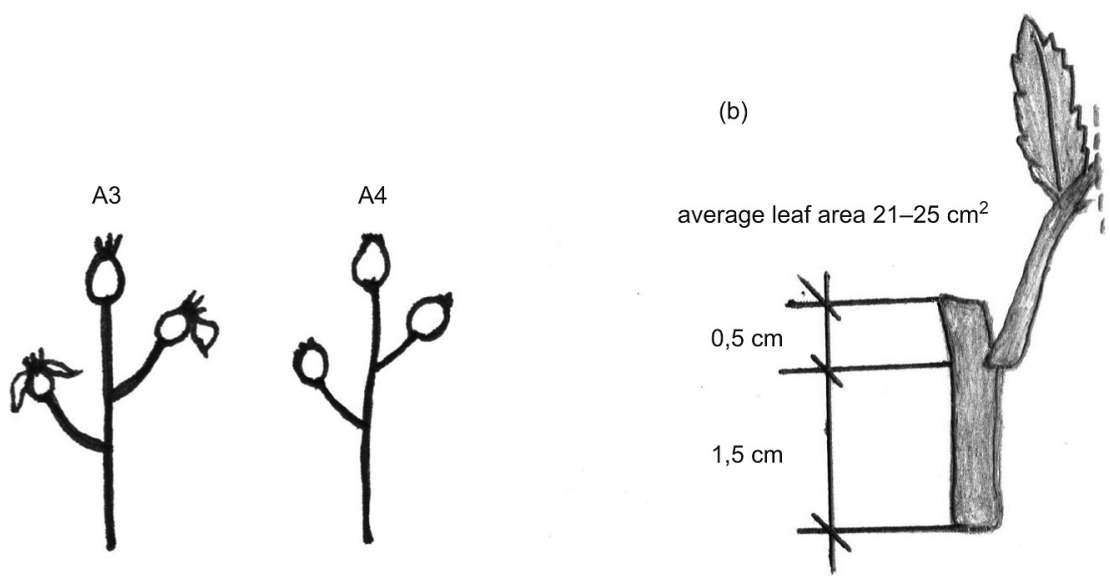

Fig. 1. The shoots of fallowing maturity phase (a) and a single node leaf cutting (b) of Rosa gallica 'Duchesse d'Angoulême'. Maturity phases (a): A1 - flower buds closed (31.05); A2 - all flowers in an inflorescence open (9.06); A3just after petal fall (17.06); A4 - 7-14 days after petal fall (29.06) 
Table 1. The treatments of cuttings of Rosa gallica 'Duchesse d'Angoulême' at each maturity phase with rooting substances in experiment.

\begin{tabular}{|c|c|c|}
\hline $\begin{array}{l}\text { No. of } \\
\text { treatment }\end{array}$ & The treatment of cuttings & $\begin{array}{l}\text { Name in } \\
\text { tables }\end{array}$ \\
\hline 1 & Control & Control \\
\hline 2 & Ukorzeniacz $\mathrm{A}_{\text {aqua }} 0.4 \%$ IBA & IBA \\
\hline 3 & 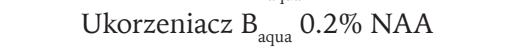 & NAA \\
\hline 4 & 0.4\% BioRhizotonic watering $(10 \mathrm{ml})$ & RH $0.4 \times 1$ \\
\hline 5 & 0.6\% BioRhizotonic & RH $0.6 \times 1$ \\
\hline 6 & 0.4\% BioRhizotonic & RH $0.4 \times 2$ \\
\hline 7 & $\begin{array}{cc}0.6 \% \text { BioRhizotonic } & \text { after cutting and } \\
10 \text { days later }\end{array}$ & RH $0.6 \times 2$ \\
\hline 8 & 0.4\% BioRhizotonic & RH $0.4 \times 3$ \\
\hline 9 & $0.6 \%$ BioRhizotonic $\begin{array}{l}\text { after cuttings, } 10 \\
\text { and } 20 \text { days later }\end{array}$ & RH $0.6 \times 3$ \\
\hline 10 & $0.1 \%$ RootJuice & RJ 0.1 \\
\hline 11 & $0.2 \%$ RootJuice & RJ 0.2 \\
\hline 12 & $0.4 \%$ RootJuice & RJ 0.4 \\
\hline 13 & $0.012 \%$ BioRoots & BR 0.012 \\
\hline 14 & $0.02 \%$ BioRoots & BR 0.02 \\
\hline
\end{tabular}

with $5 \mathrm{ml}$ of acetone. In order to neutralize organic acids a pinch of calcium carbonate has been added to the acetone. After extraction samples were transferred to a volumetric flask and adjusted to the total volume of $25 \mathrm{ml}$ with acetone. After filtering through soft blotting paper, the content of pigments was assessed spectrophotometrically by measuring absorbance at a wave length of 750;662; 645 and $470 \mathrm{~nm}$ (GeneQuant 1300, GE). The content of chlorophyll and carotenoids has been calculated according to the following formulas (Arnon 1949):

Chlorophyll $\mathrm{a}=\left(12.7 \times \mathrm{A}_{663}-2.7 \times \mathrm{A}_{645}\right) \times \mathrm{V} \times$ $(1000 \mathrm{~W})^{-1}$

Chlorophyll $\mathrm{b}=\left(22.9 \times \mathrm{A}_{645}-4.7 \times \mathrm{A}_{663}\right) \times \mathrm{V}$ $\times(1000 \mathrm{~W})^{-1}$

Carotenoids $=\left(1000 \times \mathrm{A}_{470}-1.9 \times\right.$ chlorophyll $\mathrm{a}-63.14 \times$ chlorophyll b) $\times 214^{-1}$

where: A - absorbance at a given wave length, $\mathrm{V}$ - total volume of the extract, $\left[\mathrm{cm}^{3}\right], \mathrm{W}$ - sample weight $[\mathrm{g}]$. The number of the particular pigments is quoted in $\mathrm{mg} \cdot \mathrm{g}^{-1}$ of fresh matter, while the weight of carotenoids is given in $\mathrm{mg} \cdot \mathrm{g}^{-1}$ of fresh weight.

\section{Statistical analysis}

In each studied treatment (Table 1), 20 cuttings were planted in 4 replicas (4480 cuttings). The content of proteins and pigments in leaves was determined for six repeats. All results were analysed with the ANOVA (one or two-factorial analysis of variance) procedure using STATISTICA 10 software (Statsoft Polska, Kraków). In order to evaluate significance of differences between the averages, the Duncan's (proteins and pigments) and Tukey's (percentage of cuttings) tests were used. Moreover correlation between percentage of rooted cuttings and content of pigments in the leaves and between percentage of rooted cuttings and content of proteins in the leaves in relation to biostimulants were also calculated. The data has been transformed using the function ARC$\operatorname{SIN}(\mathrm{x})^{1 / 2}$ according to Bliss or $\mathrm{y}=\mathrm{x}^{2}+\left(\mathrm{x}^{2}+1\right)^{2}$. All the tests were used at the significance level of $\alpha=0.05$.

\section{Results}

\section{Protein qualitative and quantitative changes in leaves of cuttings}

In order to describe the physiological state of used stockplants the total content of soluble protein fraction has been measured. The highest protein levels were present in leaves of mother plants at 7-14 days after petal fall (stage A4) whereas the lowest levels were observed for the all flowers opened (stage A2). Protein levels within leaves from stages A1 and A3 were similar (Fig. 2). For the stage description refer to Fig. 1.

Our further analysis has been focused on protein levels within leaves of cuttings. We found that protein content observed in 12 week old rooted cuttings was however significantly lower than levels in stockplants before rooting. Protein levels in leaves of 12 weeks old rooted cuttings were comparable in all combinations despite the different stockplant stage at the cut off time. In leaves of cuttings treated with biostimulants different levels of protein were observed depending on used preparation and maturity stage of the stockplant used at the cut off time (Fig. 2). In leaves of cuttings derived from the stage $\mathrm{A} 1$ shoots treated with Ukorzeniacz $\mathrm{B}_{\text {aqua }}$ and Root Juice $0.4 \%$ levels of protein were significantly higher comparing to leaves of representative control untreated cuttings collected at the same maturity stage of the stock plant. For cuttings taken at the stage A2 protein levels in leaves after biostimulatns treatment were comparable to representative untreated control. What is interesting for the A2 stage-derived cuttings treated with Ukorzeniacz $\mathrm{A}_{\text {aqua }}$ and Bio Rhizotonic $(3 \times$ $0.6 \%$ ) lowest levels of proteins observed in the entire experiment were present (Fig. 2). In contrast to this treatment with biostimulants significantly increased protein levels in leaves of cuttings originated from the stage A3. In case of the Ukorzeniacz $\mathrm{B}_{\text {aqua }}$ and Root Juice $0.4 \%$ protein levels observed after treatment were comparable to levels in representative stockplants at the cut off time. Observed values for these combinations were highest among the all measured samples from biostimulant treated cuttings (Fig. 2). In leaves of the stage A4 cuttings positive effects of biostimulants on the protein level were observed for Ukorzeniacz $\mathrm{B}_{\text {aqua }}$ and Bio Roots $(0.02 \%)$ treatments. Other used biostimulants had no influence on the protein levels in this phase (Fig. 2). 


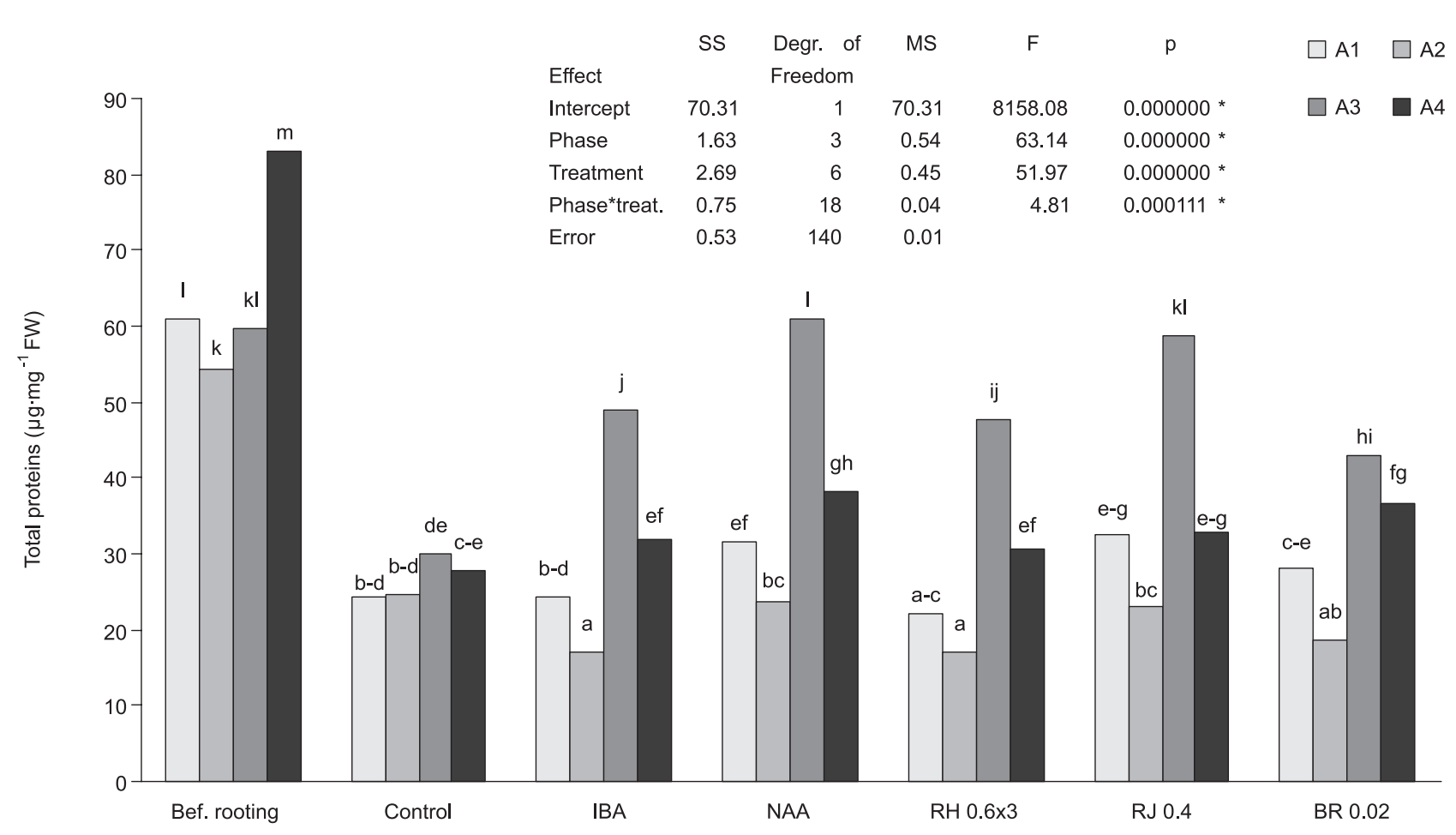

Fig. 2. Total proteins content of stem cutting's leaves of Rosa gallica 'Duchesse d'Angoulême' $\left(\mu g \cdot \mathrm{mg}^{-1} \mathrm{FW}\right)$ in four maturity phases before and after rooting with use rooting preparations. Cutting from shots: A1 - flower buds closed; A2 - all flowers in an inflorescence open; A3 - just after petal fall; A4 - 7-14 days after petal fall. Signature of the $\mathrm{x}$-axis as in Table 1. Different letters indicate significant interactions between treatment and maturity phase, according to Duncan's test $(\alpha=0.05)$

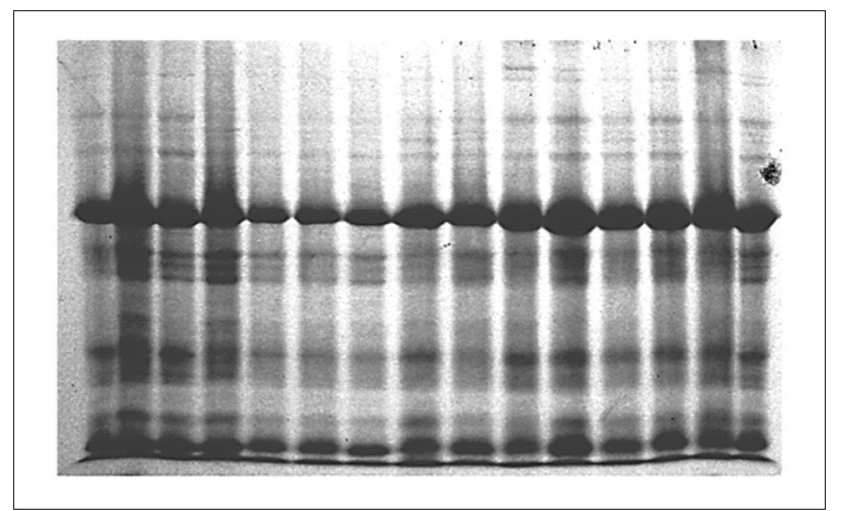

Fig. 3. Electrophoretic patterns of proteins from leaves of Rosa gallica 'Duchesse d'Angoulême' on SDS-PAGE gel. Samples of proteins extracted from leaves of rooted stem cuttings harvested after petals fall

No obvious difference in protein electrophoretic pattern has been observed suggesting this way only limited if any qualitative changes (Fig. 3).

\section{Changes in chlorophyll $\mathrm{a}$ and $\mathrm{b}$ and carotenoid content}

Our research has shown that the content of pigments in leaves of mother plants before rooting was highly determined by phenological stage of shoots. For the stockplants the highest amounts of photo- synthetic pigments were observed in leaves at the stage A3 (just after petal fall). During the later periods of vegetation at the moment at which the rooted cuttings were scored (August) the amount of chlorophyll a has decreased changing this way the chlorophyll/carotenoids as well as chlorophyll a/chlorophyll $\mathrm{b}$ content ratios.

The "mother plant effect" related to stockplant maturity at the time of cut off has been subsequently observed in leaves of rooted cuttings in combinations where no biostimulants were used (Fig. $4 \mathrm{a}-\mathrm{c}$ ). Only in leaves of cuttings originated from A1 stockplants the average amount of pigments remained at the similar level as in the leaves of mother plants. No change has been observed before rooting as well as at the time of harvest of rooted cuttings. In other combinations the content of pigments before rooting decreased, which was the most visible in leaves taken from the stage A3 stockplant (Fig. 4 a-c). Observed decrease is similar and not related to the maturity stage of the stock plant in all tested combinations (Fig. 4 a-c; Fig. 5-8). The measurements taken after rooting showed strong correlation between the content of studied pigments (chlorophyll $\mathrm{a}$ and $\mathrm{b}$ and carotenoids) and maturity phase of stockplants (Table 3 and Fig. 4 a-c).

Also the effect of biostimulants on the rooting process was related to maturity stage of used shoots (Fig. 5-8). In rooted cuttings from shoots 

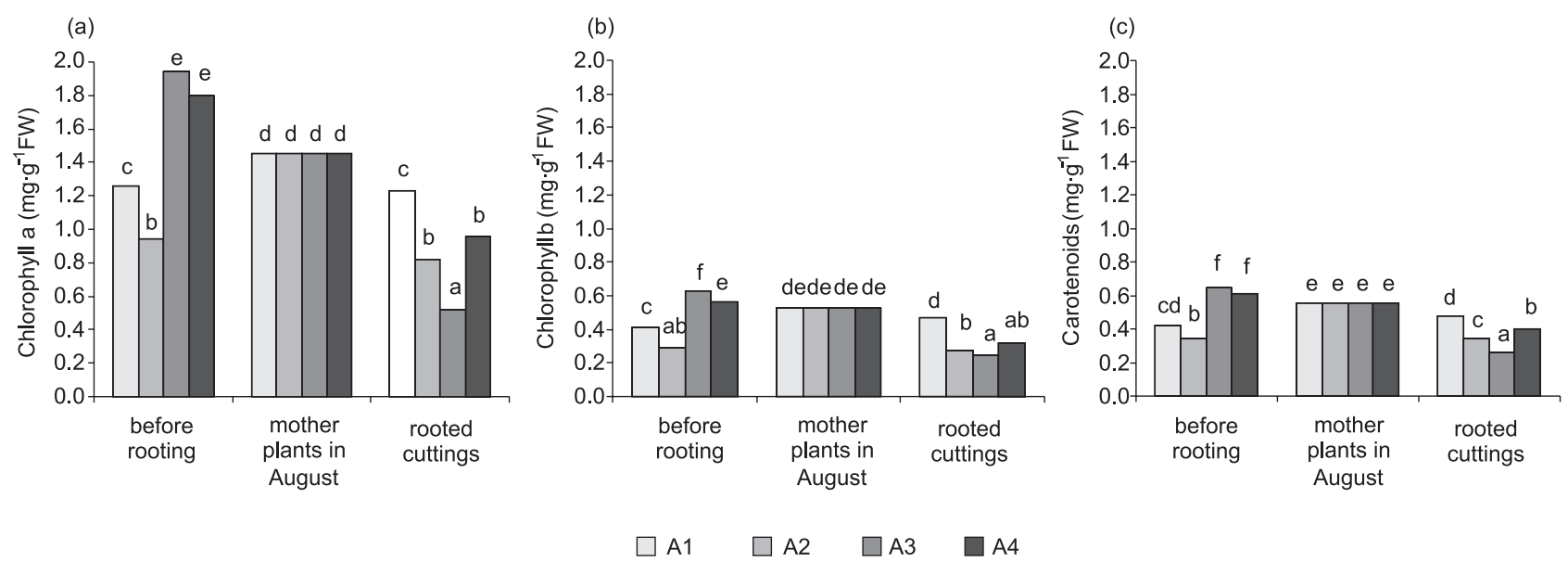

Fig. 4. The content of chlorophyll a (a), b (b), carotenoids (c) ( $\mathrm{mg}^{\circ} \mathrm{g}^{-1} \mathrm{FW}$ ) in leaves Rosa gallica 'Duchesse d'Angoulême' before rooting in June, of mother plants in August and cuttings rooted without stimulators (control), derived from four maturity phases of shoots. Maturity phase: A1 - flower buds closed; A2 - opened flowers; A3 - just after falling petals; A4 - 7-14 after falling petals. Different letters indicate significant interactions between maturity phase and origin of leaves, according to Duncan's test $(\alpha=0.05)$

with closed buds (stage A1) treated with $0.4 \%$ Bio Rhizotonic and only 1 time $0.6 \%$, the tendency for increase in chlorophyll $\mathrm{a}$ and $\mathrm{b}$ content as well as carotenoids has been observed (Fig. 5). In leaves of cuttings taken from shoots with opened flowers (stage A2), the level of examined pigments tended to slightly increase after the watering of Bio Rhizotonic an Root Juice. Decreased level of carotenoids with simultaneous high content of chlorophyll a has been observed in leaves of cuttings watered three times with the $0.6 \%$ Bio Rhizotonic (Fig. 6). In leaves of cuttings from shoots just after petal fall, the use of all rooting stimulants had a clearly positive effect on increasing the level of chlorophyll a in leaves. In case of the chlorophyll $b$ and carotenoids decreased levels were observed in leaves of control cuttings and after single watering with $0.4 \%$ and $0.6 \%$ Bio Rhizotonic (Fig. 7). For the leaves from the stage A4 cuttings increased chlorophyll a content has been observed in combination treated 3 times with $0.6 \%$ Bio Rhizotonic. Also the Ukorzeniacz $\mathrm{A}_{\text {aqua }}$ and Ukorzeniacz $\mathrm{B}_{\text {aqua }}$ had a positive influence on the content of pigments. For the A4 stage the lowest studied pigment levels were observed after use of Bio Roots and 1 and 2 time of $0.6 \%$ Bio Rhizotonic (Fig. 8).

Table 2. Effects correlation matrices between total content of proteins and percentage of rooted cuttings of Rosa gallica 'Duchesse d'Angoulême'. Marked correlations are significant at $\mathrm{p}<0,05$.

\begin{tabular}{lcc}
\hline Maturity of shoots phase & Variable & $\begin{array}{c}\text { Percentage of rooted } \\
\text { cuttings }\end{array}$ \\
\hline Flower buds closed & Percentage of rooted cuttings & 1.000 \\
All flowers in an inflores- \\
cence open
\end{tabular}


Table 3. Effects correlation matrices between percentage of rooted cuttings and pigments of Rosa gallica 'Duchesse d'Angoulême'. Marked correlations are significant at $\mathrm{p}<0.05$

\begin{tabular}{|c|c|c|c|c|c|}
\hline Maturity of shoots phase & Variable & $\begin{array}{l}\text { Percentage of } \\
\text { rooted cuttings }\end{array}$ & Chlorophyll a & Cholorophyll b & Carotenoids \\
\hline \multirow{4}{*}{ Flower buds closed } & Percentage of rooted cuttings & 1.000 & & & \\
\hline & Chlorophyll a & -0.119 & 1.000 & & \\
\hline & Chlorophyll b & -0.148 & $0.979^{*}$ & 1.000 & \\
\hline & Carotenoids & -0.249 & $0.965^{*}$ & $0.978^{*}$ & 1.000 \\
\hline \multirow{4}{*}{$\begin{array}{l}\text { All flowers in an } \\
\text { inflorescence open }\end{array}$} & Percentage of rooted cuttings & 1.000 & & & \\
\hline & Chlorophyll a & 0.108 & 1.000 & & \\
\hline & Chlorophyll b & -0.050 & $0.925^{*}$ & 1.000 & \\
\hline & Carotenoids & -0.067 & $0.965^{*}$ & $0.935^{*}$ & 1.000 \\
\hline \multirow{4}{*}{ Just after petal fall } & Percentage of rooted cuttings & 1.000 & & & \\
\hline & Chlorophyll a & 0.028 & 1.000 & & \\
\hline & Chlorophyll b & -0.011 & $0.948^{*}$ & 1.000 & \\
\hline & Carotenoids & -0.100 & $0.980^{*}$ & $0.937^{*}$ & 1.000 \\
\hline \multirow{4}{*}{$\begin{array}{l}7-14 \text { days after } \\
\text { petal fall }\end{array}$} & Percentage of rooted cuttings & 1.000 & & & \\
\hline & Chlorophyll a & -0.051 & 1.000 & & \\
\hline & Chlorophyll b & -0.197 & -0.333 & 1.000 & \\
\hline & Carotenoids & -0.259 & $0.969^{*}$ & -0.233 & 1.000 \\
\hline
\end{tabular}

Percentage of rooted cuttings in correlation with protein, chlorophyll and carotenoid content

After detailed analysis of the entire experiment we found that both, the maturity of shoots and the rooting preparations have a significant effect on rooting efficacy. The highest percentage of rooted cuttings has been achieved when material has been taken from the stage A3 stockplants. The percentage of rooting was as following: stage $\mathrm{A} 1-65.1 \%, \mathrm{~A} 2-$ $61.1 \%, \mathrm{~A} 3-75.1 \%$ and A $4-66.0 \%$.

No correlation between the positive effects of biostimulants on the content of proteins and increase in rooting efficacy after biostimulant treatment has been observed except for the combination in which cuttings derived from shoots with opened flowers were used (Table 2). We did not observe any cor-

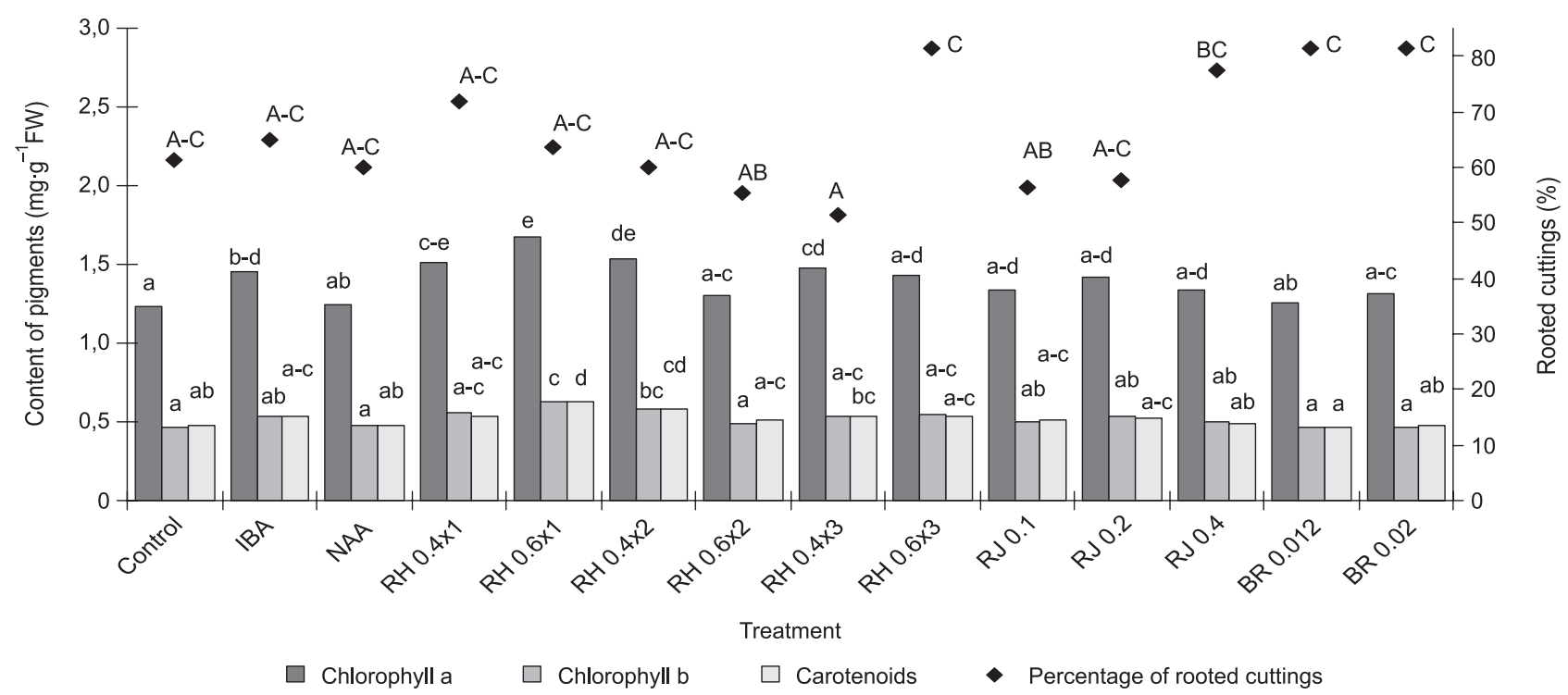

Fig. 5. The influence of rooting preparations on content of chlorophyll a and b, carotenoids (mg.g ${ }^{-1} \mathrm{FW}$ ) in leaves of cuttings and percentage of rooted cuttings of Rosa gallica 'Duchesse d'Angoulême' cut from shoots with the flower buds closed. Signature of the x-axis as in Table 1. Different letters indicate significant differences, according to Duncan's test $(\alpha=0.05)$ 


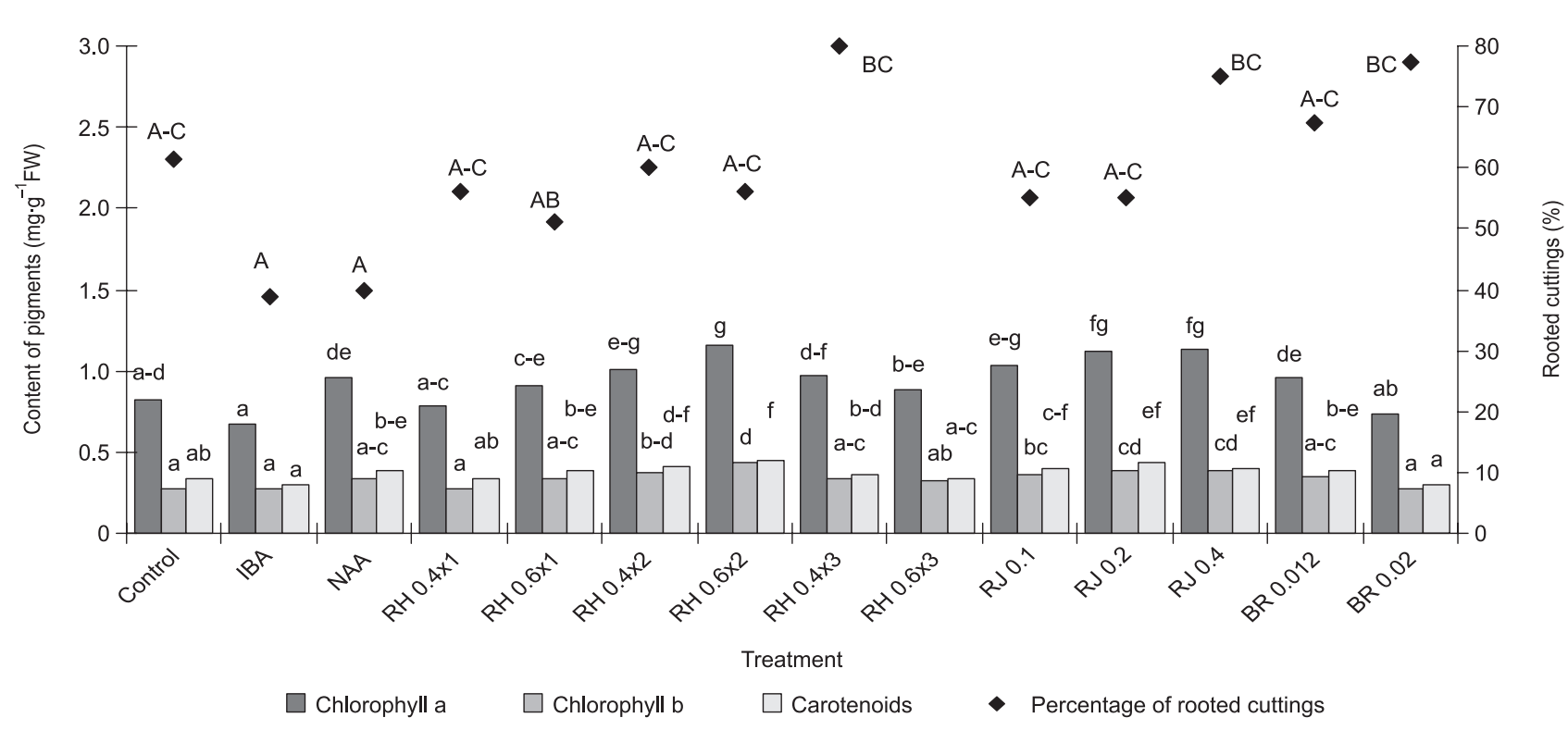

Fig. 6. The influence of rooting preparations on content of chlorophyll a and b, carotenoids (mg.g ${ }^{-1} \mathrm{FW}$ ) in leaves of cuttings and percentage of rooted cuttings of Rosa gallica 'Duchesse d'Angoulême' cut from shoots with opened flowers. Signature of the $\mathrm{x}$-axis as in Table 1. Different letters indicate significant differences, according to Duncan's test $(\alpha=0.05)$

relation between the content of pigments in leaves and increased rooting after biostimulants treatment (Table 3). The effect of used biostimulants was also influenced by the maturity state of stockplants. For cuttings obtained from A1 shoots single treatment with Bio Roots and triple treatment with $0.6 \%$ Bio Rhizotonic have positive effects on rooting (Fig. 5). For cuttings obtained from the stage A2 the best rooting has been observed when highest doses of biostimulants were used and observed results were better than in combinations with traditional IBA and NAA rooting formulations were used (Fig. 6). The highest number of the A3 cuttings were rooted when $0.2 \%$ Root Juice was used and observed rooting efficacy was larger than in a control cuttings as well as both auxin based formulations and Bio Roots. Observed rooting percentage for all used concentrations of Bio Rhizotonic and Root Juice was higher than for

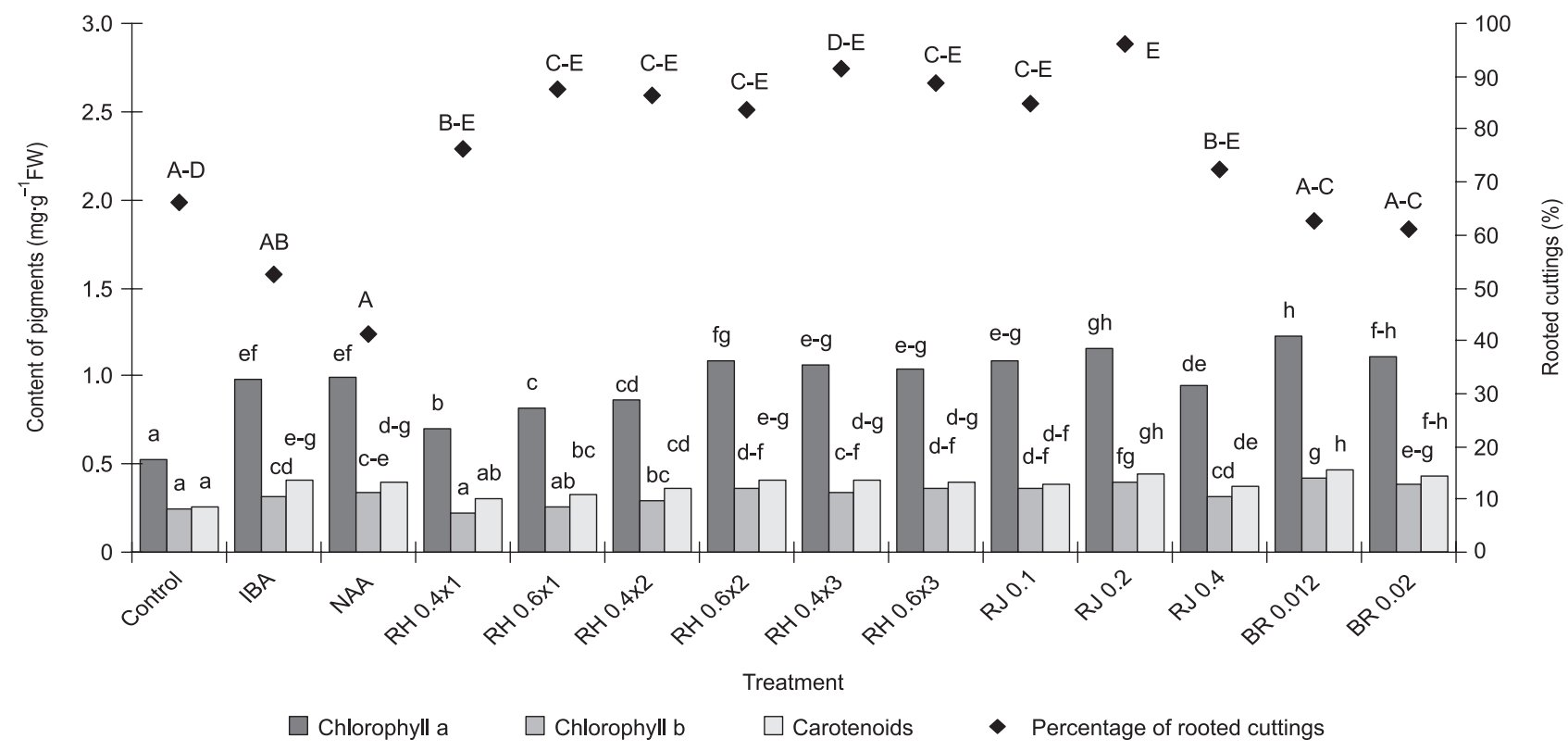

Fig. 7. The influence of rooting preparations on content of chlorophyll a and b, carotenoids $\left(\mathrm{mg} \cdot \mathrm{g}^{-1} \mathrm{FW}\right.$ ) in leaves of cuttings and percentage of rooted cuttings of Rosa gallica 'Duchesse d'Angoulême' cut from shoots just after falling petals. Signature of the x-axis as in Table 1. Different letters indicate significant differences, according to Duncan's test $(\alpha=0.05)$ 


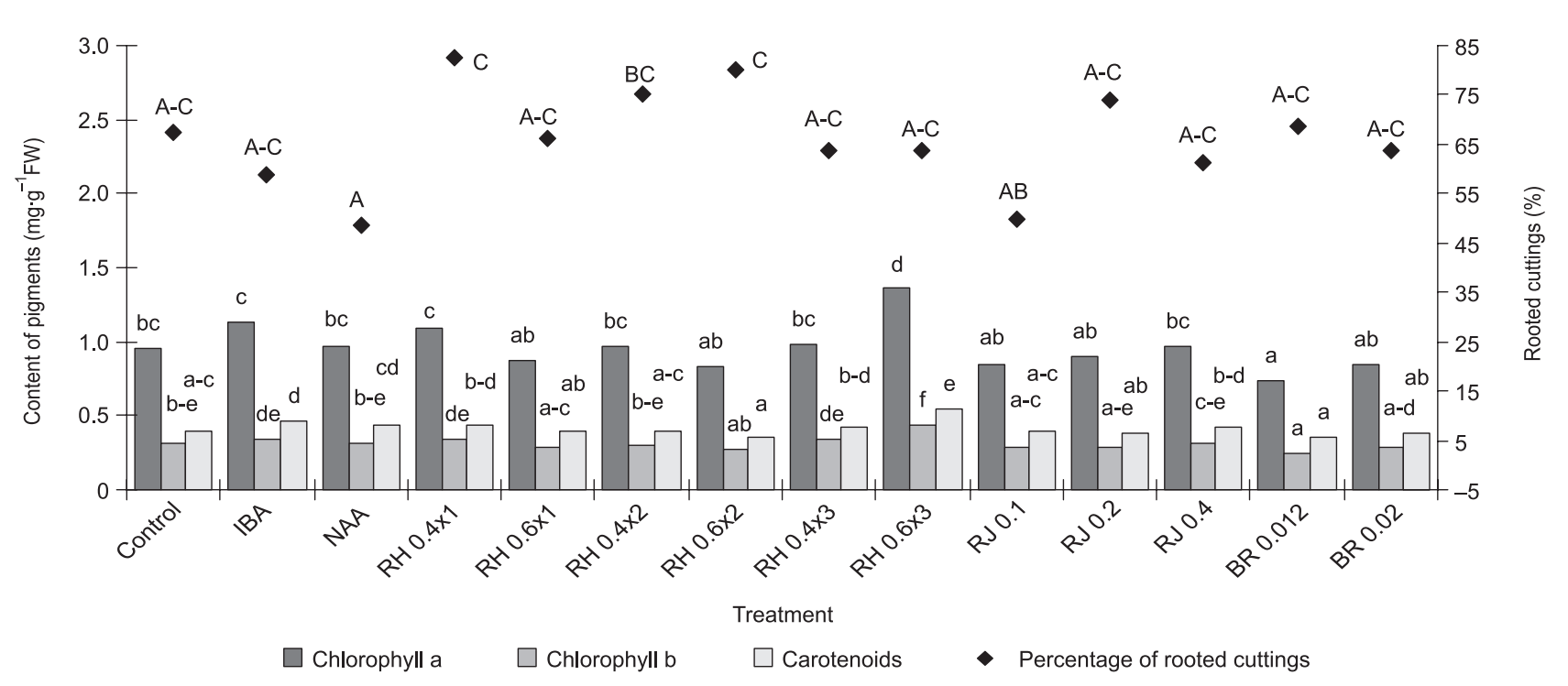

Fig. 8. The influence of rooting preparations on content of chlorophyll a and b, carotenoids $\left(\mathrm{mg}^{\circ} \mathrm{g}^{-1} \mathrm{FW}\right)$ in leaves of cuttings and percentage of rooted cuttings of Rosa gallica 'Duchesse d'Angoulême' cut from shoots 7-14 after falling petals. Signature of the x-axis as in Table 1. Different letters indicate significant differences, according to Duncan's test $(\alpha=0.05)$

Ukorzeniacz $\mathrm{B}_{\text {aqua }}$. In case of Ukorzeniacz $\mathrm{B}_{\text {aqua }}$ lowest number of rooted A3 cuttings has been obtained (Fig. 7). For the A4 phase cuttings statistical analysis has shown only minor differences in the percentage of rooting between used combinations. Similarly to A3 cuttings the lowest rooting percentage for the A4 cuttings has been observed when the Ukorzeniacz $\mathrm{B}_{\text {aqua }}$ was used. In combinations when A4 cuttings were treated once or twice with $0.4 \%$ Bio Rhizotonic as well as twice with $0.6 \%$ Bio Rhizotonic rooting percentage was improved compared to when the NAA based formulation was applied (Fig. 8).

\section{Discussion and conclusions}

Due to the long time necessary for rooting process single one-leaf node cuttings of Rosa gallica 'Duchesse d'Angoulême' are facing leaf senescence. As for cut flowers the separation from mother plant leads to senescence and visible symptom of it is a decrease of chlorophyll content in leaves. The changes in the chlorophyll content in leaves takes place before the yellowing of the leaf blade becomes visible (Skutnik and Rabiza-Świder 2004). Our research has shown that in the course of rooting of the Rosa gallica 'Duchesse d'Angoulême'decrease of studied pigments and protein content in leaves of rooted cuttings appeared and observed levels were lower than in corresponding mother plants at the time of cutting. The decrease of the chlorophyll content has been also observed in leaves of stockplants during the progress of a vegetative season. Observed phenomenon may be related to the natural senescence process.
As a consequence of it we found that the phenological phase of mother plants at the moment of harvest of cuttings have a major impact on the content of the biologically active components in leaves of rooted cuttings. We also found that the phenological stage of stockplant affects the action of preparations used for the stimulation of rhizogenesis and subsequent rooting efficacy. The practical consequence of this finding is that the knowledge on the stockplant phenological phase can be used as an important factor for successful rooting of recalcitrant rose plants.

Previous works on rose budding (Hetman and Monder 2004) and rhizogenesis of Ficus infectoria (Anand and Haberlein 1975) and Juniperus L. (Torchik 2005) also showed the correlation between the stockplant maturity and the efficacy of vegetative multiplication. Some important differences between different species and cultivars within the same genus were also reported (Torchik 2005).

In our studies we have observed similar decrease of the protein level in leaves of rooted control cuttings despite of the difference in the phenological state of the stock plant used. The highest decrease of studied pigments was observed when cuttings were acquired after petal fall (the stage A3). Noteworthy is that the A3 stage-derived cuttings had the highest rooting ability, however further more detailed studies in this subject are necessary to understand the biological meaning of this observation.

The IBA and NAA based rooting preparations (Ukorzeniacz Aaqua and Ukorzeniacz $\mathrm{B}_{\text {aqua }}$ respectively ) as well as galenical biostimulants (Bio Rhizotonic, Root Juice and Bio Roots) used in our experiment had different effects on measured param- 
eters depending on the maturity of the stockplant shoots used for cuttings. The most advantageous effects of their use on the increase of protein and pigments content were observed in rooted cuttings taken from shoots just after flower petal fall. Certain seaweed based formulations of biostimulants contain glycine betaine. It has been reported that this compound delays the loss of photosynthetic activity by inhibiting chlorophyll degradation during storage conditions in isolated chloroplasts (Genard et al. 1991; Whapham et al. 1993). In agreement to that the research of Blunden et al. (1997) and Jannin et al. (2013) shows that seaweeds and seaweed products enhance the chlorophyll content in leaves of cultivated plants. Application of a low concentration of Ascophyllum nodosum extract to soil or on foliage of tomatoes resulted in increasing chlorophyll content in leaves (Whapham et al. 1993). However, in the research Jannin et al. (2013) on Brassica napus, the chlorophyll content and net photosynthetic rate gave contradictory results after using of Ascophyllum nodosum L extract.

The current state of knowledge on the effect of biostimulants on the protein content in leaves of so called "hard to root" woody plants is rather limited. In the research carried out on different cultivars of Juniperus by Szydło (1999), no relation was found between the content of proteins and the rhizogenesis ability, however only standard powders containing IBA and NAA were used.

Taken together our studies indicate that the use of tested biostimulants in suitable concentration influence increase of chlorophyll and protein content and ability to rooting. However, changes in content of photosynthetically active pigments do not affect obtained percentage of rooted cuttings. In case of proteins only for the stage A2 the decrease in the protein content was correlated to observed decrease in rooting ability, therefore we can also say that biostimulants do not influence rooting capacity via increase in protein content. Our results confirm, that the process of rhizogenesis is complex and in optimal conditions does not rely on the delay or inhibition of senescence process in leaves. We believe that our studies clearly showed that the effect of biostimulants on rooting of woody plant cuttings does not rely on the delay of senescence however the exact action of biostimulants needs further research with help of more precise tools including the metabolomics and proteomics approaches.

\section{Acknowledgments}

The experiments was conducted by the research project no. NN 310008240, National Science Centre.

\section{References}

Afitlhile M.M. 1993. Constituent processes of leaf senescence in Hordeum vulgare cv. Dyan. Masters thesis, Rhodes University, Grahamstown, South Africa.

Anand V.K., Heberlein G.T. 1975. Seasonal changes in the effects of auxin on rooting in stem cuttings of Ficus infectoria. Physiologia Plantarum 34:330-334. http://dx.doi.org/10.1111/j.1399-3054.1975. tb03848.x

Arnon D.I. 1949. Copper enzymes in isolated chloroplasts. Polyphenoloxidase in Beta vulgaris. Plant Physiology 24: 1-15. http://dx.doi.org/10.1104/ pp.24.1.1

Bellach S., Scheewe P., Lösing H. 2009. Pflanzenstärkungsmittel in der Gehölzvermehrung. Deutsche Baumschule 2: 33-35.

Blunden G., Jenkins T., Liu Y.-W. 1997. Enhanced leaf chlorophyll levels in plants treated with seaweed extract. Journal of Applied Phycology 8: 535-543. http://dx.doi.org/10.1007/BF02186333

Cambri D., Filippini L., Apone F., Arciello S., Colucci G., Portoso D. 2008. Effect of Amino-Plant ${ }^{\circledR}$ on expression of selected genes in Arabidopsis thaliana L. plants. In: Biostimulators in modern agriculture - General Aspects. Gawrońska H. (ed.). Wieś Jutra, Warsaw, pp. 77-82.

Costa J.M.R.C. 2002. The role of the leaf in growth dynamics and rooting of leafy stem cuttings of rose. PhD thesis. Wageningen University, The Netherlands.

Couée I., Hummel I., Sulmon C., Gouesbet G., Amrani A. 2004. Involvement of polyamines in root development. Plant Cell, Tissue and Organ Culture 76: 1-10. http://dx.doi. org/10.1023/A:1025895731017

Czerpak R., Dobrzyń P., Krotke A., Kicińska E. 2002. The effect of auxins and salicylic acid on chlorophyll and carotenoid contents in Wolffia arrhiza (L.) Wimm. (Lemnaceae) growing on media of various trophicities. Polish Journal of Environmental Studies 11: 231-235.

EU Council Directive no. 91/414/EEC 1991. Official Journal of the European Union, of 15.07.1991. Dziennik Urzędowy Unii Europejskiej 03/t.11 / Dziennik Urzędowy Wspólnot Europejskich 19.8.1991 L230/1: 332-362.

Genard H., Le Saos J., Billard J.-P., Tremolieres A., Boucaud J. 1991. Effect of salinity on lipid composition, glycine betaine content and photosynthetic activity in chloroplasts of Suaeda maritima. Plant Physiology and Biochemistry 29: 421-427.

Gitelson A., Merzlyak M.N. 1994. Spectral reflectance changes associated with autumn senescence of Aesculus hippocastanum L. and Acer platanoides L. leaves. Spectral features and relation to chlo- 
rophyll estimation. Journal of Plant Physiology 143: 286-292. http://dx.doi.org/10.1016/S01761617(11)81633-0

Ghosh S., Gepstein S., Heikkila J.J., Dumbroff E.B. 1988. Use of a scanning densitometer or an ELISA Plate Reader for measurement of nanogram amounts of protein in crude extracts from biological tissues. Analytical Biochemistry 169: 227-233. http://dx.doi.org/10.1016/0003$2697(88) 90278-3$

Hetman J., Monder M.J. 2004. Wpływ dojrzałości zrazów oraz umiejscowienia oczka na pędzie na wzrost i jakość uzyskanych krzewów dwóch odmian róż z grupy wielkokwiatowych. Część I. Parametry wzrostu krzewów. Acta Scientiarum Polonorum Hortorum Cultus. 3: 13-21.

Hoşafçi H., Arslan N., Sarihan E.O. 2005. Propagation of dogrose (Rosa canina L.) plants by softwood cuttings. Acta Horticulturae 690: 139-142.

Jannin L., Arkoun M., Etienne P., Laïné P., Goux D., Garnica M., Fuentes M., Francisco S.S., Baigorri R., Cruz F., Houdusse F., Garcia-Mina J.-M., Yvin J.-C., Ourry A. 2013. Brassica napus growth is promoted by Ascophyllum nodosum (L.) Le. Jol. Seaweed extract: microarray analysis and physiological characterization of N, C, and S metabolisms. Journal of Plant Growth Regulation 32: 31-52. http://dx.doi.org/10.1007/s00344-012-9273-9

Khan W., Rayirath U.P., Subramanian S., Jithesh M.N., Rayorath P., Hodges D.M., Critchley A.T., Craigie J.S., Norrie J., Prithiviraj B. 2009. Seaweed extracts as biostimulants of plant growth and development. Journal of Plant Growth Regulation 28: 386-399. http://dx.doi.org/10.1007/s00344009-9103-x

Moberg U., Winter A., Hyden N., Ek K. 1987. Analysis of monoclonal antibodies during production and purification. A review of electrophoretic methods. LKB Application Note: 474.

Monder M.J. 2007. Zasoby genowe i ocena wybranych odmian róż historycznych. Zeszyty Problemowe Postępów Nauk Rolniczych 517: 487-494.

Moroz E.K. 2006. Korniesoobstwiennyje rozy w Nacionalnom Parkie 'Sofiewka'. Nacionalna Akademia Nauk Ukrainy, Centralny Botanicznyj Sad. Umań.
Okoro O.O., Grace J. 1976. The physiology of rooting Populus cuttings. I. Carbohydrates and photosynthesis. Physiologia Plantarum 36: 133-138. http://dx.doi.org/10.1111/j.1399-3054.1976. tb03923.x

Pruszyński S. 2008. Biostimulators in plant protection. In: Biostimulators in modern Agriculture General Aspects. Gawrońska H. (ed.). Wieś Jutra, Warsaw, pp. 18-23.

Quest-Ritson C., Quest-Ritson B. 2003. The Royal Horticultural Society Encyclopedia of Roses. Dorling Kindersley. London, p. 128.

Ranwala A.P., Miller W.B. 2002. Effects of gibberellin treatments on flower and leaf quality of cut hybrid lilies. Acta Horticulturae 570: 205-210.

Skutnik E., Rabiza-Świder J. 2004. Longevity of cut shoots of Molucella laevis L. as affected by flower preservatives and growth regulators. Folia Horticulturae 16: 167-173.

Szydło W.B. 1999. Intensyfikacja procesu rozmnażania krzewów ozdobnych przez sadzonki pędowe. $\mathrm{PhD}$ thesis. University of Life Science, Warsaw, Poland.

Thorsen M.K., Woodward S., McKenzie B.M. 2010. Kelp (Laminaria digitata) increases germination and affects rooting and plant vigour in crops and native plants from an arable grassland in the Outer Hebrides, Scotland. Journal of Coastal Conservation 14: 239-247. http://dx.doi.org/10.1007/ s11852-010-0091-6

Torchik V. 2005. Effect of donor plant phonological phase on root formation of stem cuttings of ornamental Juniperus L. cultivars. Propagation of Ornamental Plants 5: 51-55.

Volfová A., Chvojka L., Friedrich A. 1978. The effect of kinetin and auxin on the chloroplast structure and chlorophyll content in wheat coleoptiles. Biologia Plantarum 20: 440-445. http://dx.doi. org/10.1007/BF02923348

Whapham C.A., Blunden G., Jenkins T., Hankins S.D. 1993. Significance of betaines in the increased chlorophyll content of plants treated with seaweed extract. Journal of Applied Phycology 5: 231-234. http://dx.doi.org/10.1007/BF00004023

Wojdyła A.T. 2004. Effectiveness of Atonik SL in the control of powdery mildew, black spot and rust. Folia Horticulturae 16: 175-181. 